\title{
Is It Possible to Differentiate Pneumocystis jirovecii Pneumonia and Colonization in the Immunocompromised Patients with Pneumonia?
}

\author{
Yudy A. Aguilar 1,2,*, Zulma Vanessa Rueda ${ }^{2,3}{ }^{\mathbb{D}}$, María Angélica Maya ${ }^{1,4}{ }^{\mathbb{D}}$, Cristian Vera ${ }^{2}$, Jenniffer Rodiño ${ }^{1}$, \\ Carlos Muskus ${ }^{5}$ and Lázaro A. Vélez ${ }^{1,4}$
}

1 Grupo Investigador de Problemas en Enfermedades Infecciosas-GRIPE, Facultad de Medicina, Universidad de Antioquia, Medellín 050031, Colombia; mangelicamaya@gmail.com (M.A.M.); jmedarom_12@yahoo.es (J.R.); lazarovelezg@gmail.com (L.A.V.)

2 Facultad de Medicina, Universidad Pontificia Bolivariana, Medellín 050031, Colombia; zulmaruedav@gmail.com (Z.V.R.); cristian.vera.marin@hotmail.com (C.V.)

3 Department of Medical Microbiology and Infectious Diseases, University of Manitoba, Winnipeg, MB R3E 0J9, Canada

4 Section of Infectious Diseases, Hospital Universitario San Vicente Fundación, Medellín 050010, Colombia

5 Unidad de Biología Molecular y Computacional, Programa de Estudio y Control de Enfermedades Tropicales-PECET, Facultad de Medicina, Universidad de Antioquia, Medellín 050010, Colombia; carmusk@yahoo.com

* Correspondence: yudyagui@gmail.com; Tel.: +57-4-448-8388 (ext. 19323)

\section{check for} updates

Citation: Aguilar, Y.A.; Rueda, Z.V.; Maya, M.A.; Vera, C.; Rodiño, J.;

Muskus, C.; Vélez, L.A. Is It Possible to Differentiate Pneumocystis jirovecii Pneumonia and Colonization in the Immunocompromised Patients with Pneumonia? J. Fungi 2021, 7, 1036. https://doi.org/10.3390/jof7121036

Academic Editors: Enrique J. Calderón, Robert F. Miller and Yaxsier de Armas

Received: 31 August 2021

Accepted: 19 November 2021

Published: 2 December 2021

Publisher's Note: MDPI stays neutral with regard to jurisdictional claims in published maps and institutional affiliations.

Copyright: (c) 2021 by the authors. Licensee MDPI, Basel, Switzerland. This article is an open access article distributed under the terms and conditions of the Creative Commons Attribution (CC BY) license (https:/ / creativecommons.org/licenses/by/ $4.0 /)$.
Abstract: Respiratory sample staining is a standard tool used to diagnose Pneumocystis jirovecii pneumonia $(\mathrm{PjP})$. Although molecular tests are more sensitive, their interpretation can be difficult due to the potential of colonization. We aimed to validate a Pneumocystis jirovecii (Pj) real-time PCR (qPCR) assay in bronchoscopic bronchoalveolar lavage (BAL) and oropharyngeal washes (OW). We included 158 immunosuppressed patients with pneumonia, 35 lung cancer patients who underwent BAL, and 20 healthy individuals. We used a SYBR green qPCR assay to look for a $103 \mathrm{bp}$ fragment of the $\mathrm{Pj} m t L S U$ rRNA gene in BAL and OW. We calculated the qPCR cut-off as well as the analytical and diagnostic characteristics. The qPCR was positive in $67.8 \%$ of BAL samples from the immunocompromised patients. The established cut-off for discriminating between disease and colonization was $\mathrm{Ct}$ 24.53 for BAL samples. In the immunosuppressed group, qPCR detected all 25 microscopy-positive $\mathrm{PjP}$ cases, plus three additional cases. Pj colonization in the immunocompromised group was $66.2 \%$, while in the cancer group, colonization rates were $48 \%$. qPCR was ineffective at diagnosing $\mathrm{PjP}$ in the OW samples. This new qPCR allowed for reliable diagnosis of PjP, and differentiation between $\mathrm{PjP}$ disease and colonization in BAL of immunocompromised patients with pneumonia.

Keywords: quantitative real time PCR; Pneumocystis jirovecii; pneumonia; colonization; bronchoalveolar lavage (BAL); oropharyngeal washes (OW)

\section{Introduction}

Pneumocystis jirovecii pneumonia (PjP) affects patients with severe immunosuppression, such as those with an acquired immunodeficiency syndrome (AIDS), autoimmune diseases of the connective tissue, and hematological malignancies, as well as the organ transplant recipients. Although $\mathrm{PjP}$ can be lethal in up to $80 \%$ of cases [1], most patients survive when treated with trimethoprim-sulfamethoxazole (TMS/SMX) [2]. Diagnosis of $\mathrm{PjP}$ is based on a microscopic visualization of the fungus in respiratory samples (from both bronchoalveolar lavage [BAL] and induced/spontaneous sputum) using special stains such as methenamine silver, toluidine blue $\mathrm{O}$ (TBO), or direct fluorescent antibody (DFA). A positive microscopy for $P$. jirovecii $(\mathrm{Pj})$ in respiratory secretions is sufficient for the diagnosis of PjP [3]. 
Introduction of molecular techniques has allowed for the detection of $\mathrm{Pj}$ genetic material in invasive and non-invasive respiratory samples, such as oropharyngeal washes (OW) [4-6], even in asymptomatic and healthy individuals, demonstrating that a positive result can be indicative of either colonization or disease [7-9].

However, when considering the pathophysiology of $\mathrm{PjP}$, it is logical to assume that a high respiratory fungal load suggests a disease since lung damage and symptoms largely depend on a fungal load present within the alveoli. It has been shown that increased Pneumocystis load produces pro-inflammatory cytokines and surfactant proteins that change the surface tension and lead to a gas exchange failure and respiratory deterioration of the patient $[10,11]$. Consequently, techniques that quantify Pneumocystis load, such as quantitative PCR (qPCR), would help establish a threshold for discriminating between disease and colonization. However, cut-off values reported thus far in GPCR protocols often generate indeterminate test results due to the overlapping values $[4,12-26]$. These inconsistencies may be partially attributed to the differences among the immunocompromised study populations, in addition to the technical aspects associated with the qPCR protocols (i.e., different target sequences, qPCR platforms, detection or extraction methods, amount of DNA in a sample, normalization of samples with a simultaneous amplification of human genes), or to the way the results are reported.

On the other hand, the term colonization (also known as "carrier") has been used when a fungus is detected by the nucleic acid amplification techniques in asymptomatic individuals [27]. However, symptomatic respiratory patients with tuberculosis, systemic mycosis, and other pulmonary diseases may also become colonized by $\mathrm{Pj}$ or other potential pathogens. Thus, to appropriately interpret a positive result among these individuals, quantitative techniques, such as qPCR, need to consider that a positive qPCR result may not necessarily mean PjP.

Based on the aforementioned limitations, we aimed to clinically validate a qPCR assay that allows for PjP diagnosis, and discrimination between colonization and disease (PjP) in immunocompromised patients with suspected $\mathrm{PjP}$. We also described their characteristics and follow-up according to Pj status.

\section{Materials and Methods}

\subsection{Study Design}

The study was a prospective cohort study.

\subsection{Inclusion and Exclusion Criteria}

The following groups were prospectively recruited:

Group 1: Immunocompromised patients with pneumonia between June 2007-January 2010. We hired a full-time clinician that went every day to the emergency room to identify all people who were admitted to the two hospitals with a suspicion of pneumonia. Then, she reviewed the clinical chart, contacted the patient, and if the patient met the inclusion criteria and none of the exclusion criteria, she enrolled the patient in the study and took the OW. Only a single episode of pneumonia was included per patient. We collected bronchoscopic BAL and OW samples from each patient.

a. Follow-up: Until discharge or death. During hospitalization, we recorded information on patient demographics, past clinical history, clinical information for the current episode, laboratory parameters, and the presence of mycobacteria, fungi, and pyogenic bacteria, in both BAL and blood samples. After hospitalization, each participant was followed up with at 6 and 12 months by phone call, to ask about new hospitalizations (date(s) and reason for hospitalization(s)), survival, antiretroviral treatment, and prophylaxis with TMS/SMX. We also reviewed the clinical chart to identify if the patient was hospitalized (date(s) and reason for hospitalization(s)) during the year of follow-up and the survival. 
Group 2: Patients with lung cancer (a known risk factor for Pj colonization [28]) who had undergone BAL to confirm the diagnosis of neoplasia were included between October 2007 and March 2010, and had BAL and OW samples collected.

Group 3: Immunocompetent individuals (blood donors) aged 18 and 65 years old, who had no known comorbidities or respiratory symptoms, and who, according to the literature, had a low risk of colonization by $\mathrm{Pj}$ [29-32]. This group was recruited between November 2010 and February 2011 and had OW samples collected. Groups 2 and 3 were chosen to evaluate $\mathrm{qPCR}$ in people with differing risks of $\mathrm{Pj}$ colonization.

Details of the inclusion and exclusion criteria are listed in Table 1.

\subsection{Setting}

The study was set in two tertiary institutions (Hospital San Vicente Fundación and Hospital La María) in Medellín, Colombia.

\subsection{Collection of Respiratory Samples and Microscopy}

Each bronchoscopic BAL sample was obtained according to the standardized protocols [33] at each institution, and 5 to $20 \mathrm{~mL}$ of the sample was sent to our laboratory. OW was taken within the first $48 \mathrm{~h}$ of BAL. After oral washing with a sterile saline solution to eliminate any food remnants, OW was performed using $25 \mathrm{~mL}$ of $0.9 \%$ saline solution for $60 \mathrm{~s}$ [34]. To increase cell recovery, an oropharyngeal rayon tip swab (COPAN DIAGNOSTICS ${ }^{\circledR}$, Corona, CA, USA) was collected from each patient and placed in a container with the OW sample.

Volumes of 3-5 mL of the BAL samples and $10 \mathrm{~mL}$ of the OW samples were cytocentrifuged within the first $24 \mathrm{~h}$ and used to prepare TBO and DFA slides, as described by Rodiño et al. [35]. The presence of human cells was microscopically verified in all the samples. The remaining sample was coded for blind processing and stored at $-80{ }^{\circ} \mathrm{C}$ for DNA extraction.

\subsection{Definitions}

Pneumocystis jirovecii pneumonia was defined as:

Confirmed: The patient had pneumonia as defined in Table 1 and had a positive result by TBO and/or DFA in the BAL sample.

Probable: A positive qPCR below the cut-off established as a threshold for PjP diagnosis, the patient had an interstitial pneumonia (pneumonia as defined in Table 1 and bilateral interstitial infiltrates in the chest X-ray or ground-glass pattern in the high-resolution computed tomography), with a negative result by TBO and DFA in the BAL sample, with no other microbiological diagnosis that explained the pneumonia, and had clinical improvement with treatment dose of PjP.

The research team did not participate and were not involved in any clinical decision from the infectious disease specialists or pulmonologists in charge of the patient. The research laboratory delivered the TBO and DFA results to the clinicians in charge of the patients immediately after the BAL samples were processed. As the qPCR was under development, we did not provide any qPCR result to the clinicians.

\subsection{DNA Extraction Protocol}

After gradually thawing the samples, $2 \mathrm{~mL}$ of the BAL samples and $10 \mathrm{~mL}$ of the $\mathrm{OW}$ samples were centrifuged at 4500 r.p.m. for $20 \mathrm{~min}$ at $4{ }^{\circ} \mathrm{C}$. The pellet was resuspended in $200 \mu \mathrm{L}$ of the same supernatant. DNA extraction was performed according to modified DNeasy Blood \& Tissue Kit protocol instructions (QIAGEN ${ }^{\circledR}$, Hilden, Germany), with the proteinase $\mathrm{K}$ and $\mathrm{AL}$ buffers added prior to incubation at $56{ }^{\circ} \mathrm{C}$. 
Table 1. Eligibility criteria of the 3 different groups included in the study.

\begin{tabular}{|c|c|c|c|}
\hline & $\begin{array}{c}\text { Group 1 } \\
\begin{array}{c}\text { Immunocompromised People } \\
\text { with Pneumonia }\end{array}\end{array}$ & $\begin{array}{c}\text { Group } 2 \\
\text { People with Suspicion } \\
\text { of Lung Cancer } \\
\text { without Pneumonia }\end{array}$ & $\begin{array}{c}\text { Group } 3 \\
\text { Healthy Blood Donors }\end{array}$ \\
\hline $\begin{array}{l}\text { Inclusion } \\
\text { criteria }\end{array}$ & $\begin{array}{l}\text { Individuals must have met all of the } \\
\text { following criteria: } \\
\text { 1. } \\
\text { 2. } 18 \text { years } \\
\text { Have at least one of the following } \\
\text { severe immunosuppression } \\
\text { conditions: primary } \\
\text { immunodeficiencies, AIDS (with } \\
\text { CD4+ T lymphocyte count } \\
\leq 200 / \mu \text { L or category C, or CD4+ } \\
\text { had decreased } \geq 50 \% \text { in the past } \\
6 \text { months), solid organ or bone } \\
\text { marrow transplant, hematologic } \\
\text { neoplasia, CD4+ T lymphocyte } \\
\text { count } \leq 200 / \mu L \text { from other causes } \\
\text { distinct from AIDS, and other } \\
\text { diseases that cause cellular } \\
\text { immunity deterioration such as } \\
\text { cancer and autoimmune diseases of } \\
\text { the connective tissue, that required } \\
\text { treatment with } \\
\text { immunosuppressant drugs such as } \\
\text { prednisone, } 0.3 \text { mg/k/d or its } \\
\text { equivalent, for more than } 2 \text { weeks. } \\
\text { People with pneumonia defined as } \\
\text { the presence of respiratory } \\
\text { symptoms (at least one of the } \\
\text { following symptoms: cough, } \\
\text { dyspnea, pleuritic pain, } \\
\text { hemoptysis) or fever } \geq 37.8{ }^{\circ} \mathrm{C}, \text { and } \\
\text { with at least one of the following: } \\
\text { abnormal breath sounds on lung } \\
\text { auscultation or pulmonary } \\
\text { opacities in the chest } \\
\text { X-ray or high-resolution } \\
\text { computed tomography. } \\
\text { Underwent bronchoscopic } \\
\text { bronchoalveolar lavage (BAL). } \\
\text { Agreed to participate in the study. }\end{array}$ & $\begin{array}{l}\text { Individuals must have met all } \\
\text { of the following criteria: } \\
\text { 1. } \geq 18 \text { years } \\
\text { 2. BAL was obtained as } \\
\text { part of the study } \\
\text { to confirm lung } \\
\text { cancer diagnosis } \\
\text { 3. Agreed to participate in } \\
\text { the study }\end{array}$ & $\begin{array}{l}\text { Individuals must have met all of the } \\
\text { following criteria: } \\
\text { 1. Immunocompetent and } \\
\text { between } 18 \text { and } 65 \text { years old } \\
\text { 2. No symptoms of acute } \\
\text { respiratory tract infection at the } \\
\text { time of OW sampling or any } \\
\text { other type of respiratory } \\
\text { infection in the past month } \\
\text { 3. No heart disease or chronic } \\
\text { pulmonary disease } \\
\text { No pregnancy } \\
\text { 5. No immunosuppression: } \\
\text { a. No corticosteroids or other } \\
\text { immunosuppressing therapy } \\
\text { for any reason in the } \\
\text { past } 3 \text { months } \\
\text { No hematological or invasive } \\
\text { cancer in the past } 5 \text { years } \\
\text { b. } \begin{array}{l}\text { Diabetes, autoimmune } \\
\text { disease, or } \\
\text { granulocytopenia }<500 \\
\text { cell/mm } 3\end{array}\end{array}$ \\
\hline
\end{tabular}

1. Those who received more than 5 days of treatment dose of $\mathrm{PjP}$ (not prophylactic treatment):

Exclusion trimethoprim/sulfamethoxazole criteria $\quad(15 / 75 \mathrm{mg} / \mathrm{kg} /$ day $)$ or clindamycin + primaquine.

2. Oral wash not taken within $48 \mathrm{~h}$ of BAL.
1. Those with lung infection or antimicrobial treatment Those who had been in a hospital in at the time of BAL

2. Oral wash not taken the past month for more than $4 \mathrm{~h}$ /day

\section{7. qPCR Assay}

For the real-time PCR assay that quantified $\mathrm{Pj}$, we amplified a fragment of the mitochondrial large subunit ribosomal RNA (mtLSU rRNA) gene [36]. The qPCR targeting the $108 \mathrm{bp}$ mtLSU rRNA region was performed in $25 \mathrm{uL}$ containing $0.3 \mu \mathrm{M}$ of each 
primer (PJ mtLSU Forw (5'- AAGGGAAACAGCCCAGAACA-3') and PJ mtLSU Rev (5' - CTGTTTCCAAGCCCACTTCTT-3' $)$, 1X SYBR-green QuantiFast $\left(\right.$ QIAGEN $^{\circledR}$, Hilden, Germany)) and $5 \mu \mathrm{L}$ of DNA from the samples or plasmid. All reactions were conducted in a SmartCycler thermocycler (Cepheid ${ }^{\circledR}$, Sunnyvale, CA, USA) employing an initial cycle of $10 \mathrm{~min}$ at $95^{\circ} \mathrm{C}$, followed by 37 cycles each at $95^{\circ} \mathrm{C}$ for $30 \mathrm{~s}, 65^{\circ} \mathrm{C}$ for $30 \mathrm{~s}$, and $72{ }^{\circ} \mathrm{C}$ for $20 \mathrm{~s}$. A positive and specific reaction was defined as a threshold cycle $(\mathrm{Ct}) \mathrm{be}-$ tween 10 and 36.99 and a $\mathrm{Tm}$ of $77^{\circ} \mathrm{C} \pm 2{ }^{\circ} \mathrm{C}$. A linear dynamic range of qPCR between 50 and $2 \times 10^{8}$ copies / $\mu \mathrm{L}$ had high reproducibility $(\mathrm{CV}<4 \%)$, amplification efficiencies close to $100 \%$ (slopes of $-3.2(\bar{x}: 3.24 \pm 0.02)$ ), and standard curves with coefficients of determination $\left(R^{2}\right)$ higher than $0.98(\bar{x}: 0.996 \pm 0.01)$.

Positive and negative controls were included in all qPCR assays. The efficiency of each positive reaction was determined using LinReg software [37]. If samples did not amplify, the presence of inhibitors was ruled out by amplifying a fragment of $\beta$-globin or glyceraldehyde-3-phosphate dehydrogenase (GAPDH) human genes by conventional PCR. All procedures and sample handling were conducted according to Clinical and Laboratory Standards Institute (CLSI) [38-40] and the European molecular diagnostic guidelines [41].

\subsection{Sample Size and Study Population}

A sample size of $133 \mathrm{OW}$ was estimated based on (a) PjP prevalence of $18 \%$ among severely immunocompromised patients with pneumonia [33], (b) 95\% power, (c) 99\% specificity for microscopy (the test reference), and (d) a specificity of $85 \%$ in OW [5] for qPCR when the MSG gene was amplified amplifying the major surface glycoprotein (MSG) gene.

\subsection{Statistical Analysis}

Data were analyzed using the SPSS version 26.0 (SPSS ${ }^{\circledR}$ Inc., Chicago, IL, USA) and Epidat $^{\circledR}$ version 4 (Xunta de Galicia, Santiago de Compostela, Spain, and Pan American Health Organization) statistical software. To establish a qPCR cut-off, the prospectively recruited patients from group 1 were used since they had provided the necessary information and their samples had been processed immediately for the microscopic visualization.

The cut-off was established using the receiver operating characteristic (ROC) curve to determine the highest sensitivity and specificity using microscopy results (TBO and/or DFA) as the reference test. The sensitivity, specificity, and positive and negative predictive values are reported for group 1.

We used Chi-squared and Mann-Whitney U-tests to explore differences in the frequency of $\mathrm{PjP}$ and colonization compared to non-infected by $\mathrm{Pj}$. The prevalence ratio (PR) with a $95 \%$ confidence interval is reported.

\section{Results}

\subsection{Diagnostic Validation of $q P C R$ in $B A L$}

We included 213 individuals: 158 immunocompromised patients, 35 with suspected lung cancer, and 20 healthy subjects without any indication for BAL, in which only OW was taken (Figure 1).

Among the immunocompromised patients, 79.7\% were infected with the human immunodeficiency virus (HIV)/AIDS, 13.9\% were transplant recipients, $3.2 \%$ had a connective tissue autoimmune disease and were taking immunosuppressants, and 3.3\% had hematologic neoplasia. Majority of the HIV/AIDS patients with available CD4 counts were severely immunosuppressed (CD4 count: median, 53 cell/ $/ \mathrm{mm}^{3}$, IQR 16-126; CD4 < 200 cell $/ \mathrm{mm}^{3}: 88.5 \%$ ) (Table 2 ). 


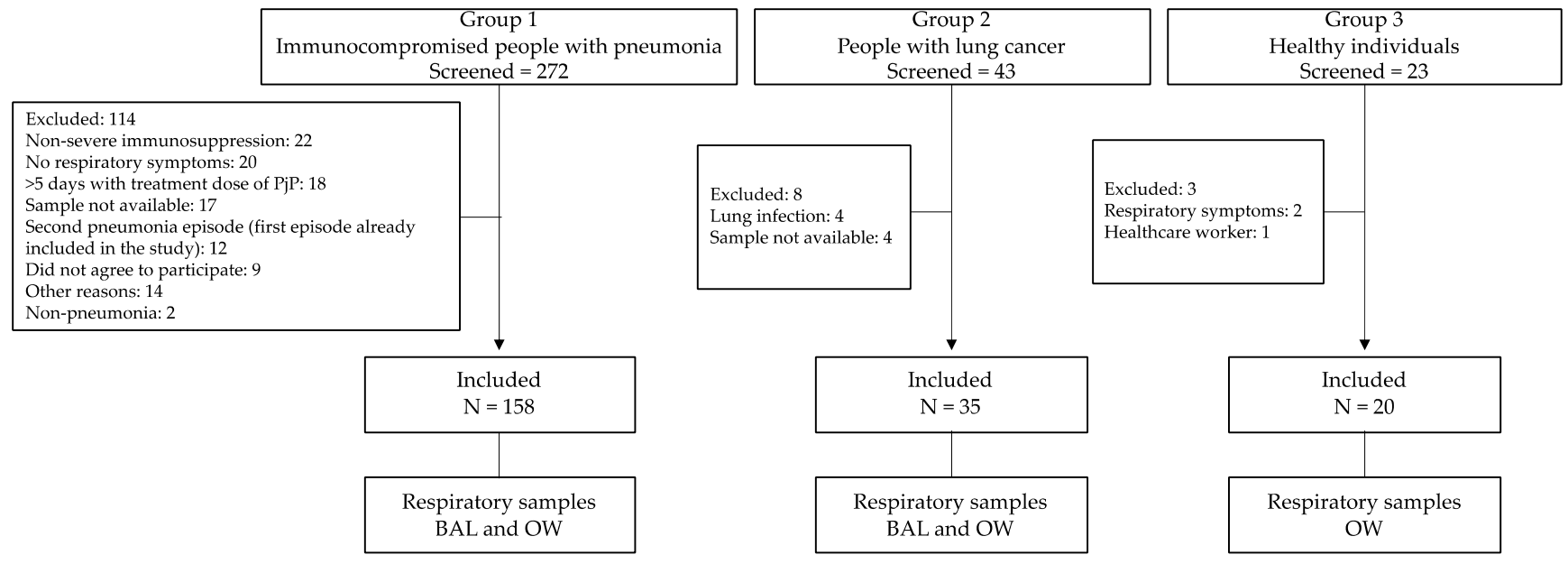

Figure 1. Flowchart of the study, including the type of respiratory samples analyzed in each group. BAL: Bronchoalveolar lavage. OW: Oral wash. PjP: Pneumocystis jirovecii pneumonia.

In total, 25 cases of PjP were diagnosed by TBO and/or DFA; of those, 24 cases (96\%) were HIV-positive patients, and $1(4 \%)$ had undergone a kidney transplantation.

Among the immunocompromised patients, $\mathrm{qPCR}$ was positive in $72.2 \%$ of the BAL samples (114/158), and Ct values ranged from 13.99 and 36.99. Among patients with microscopically confirmed $\mathrm{PjP}$, median $\mathrm{Ct}$ values were lower than the $\mathrm{Pj}$ negative cases by microscopy (18.16, IQR 16.47-21.55 vs. 33.80, IQR 30.90-35.42, $p<0.0001$ ).

Based on the BAL sample ROC curves from immunocompromised patients (group 1), we determined that the $\mathrm{Ct}$ value of 24.53 was the best cut-off to discriminate between PjP disease and colonization (sensitivity 100\% (CI 95\% 98-100), specificity 97.7\% (CI 95\% 94.8-100), positive predictive value $89.3 \%$ (CI 95\% 76.0-100), negative predictive value $100 \%$ (CI 95\% 99.6-100), area under the curve (AUC) ROC $0.985,95 \%$ CI 0.953 to 1.00) (Figure 2A). A Ct value lower than 24.53 was defined as $\mathrm{PjP}$ (confirmed or probable), while $\mathrm{Ct}$ values higher than the established threshold were considered to represent colonization.

A.

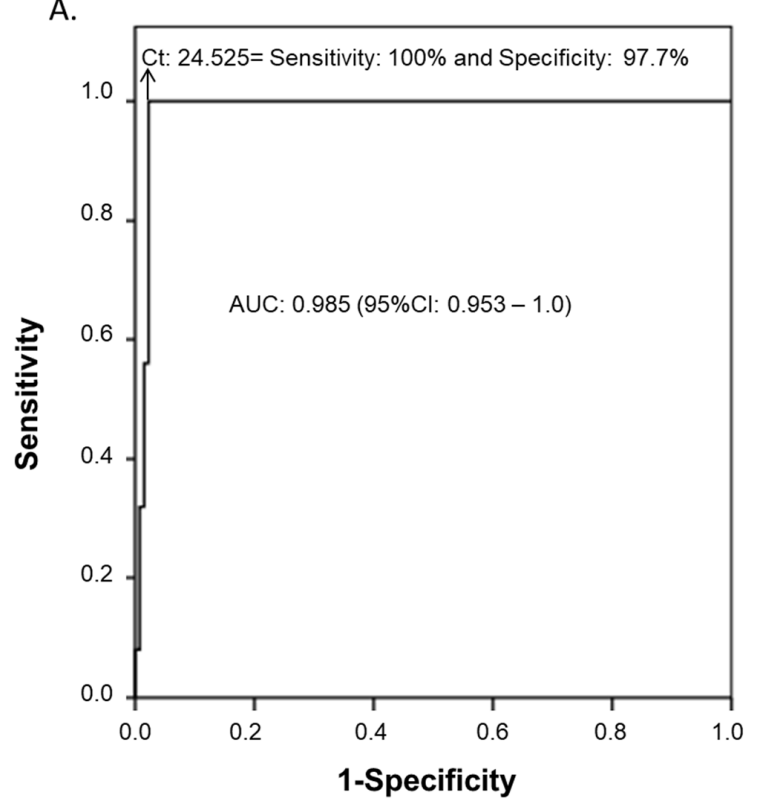

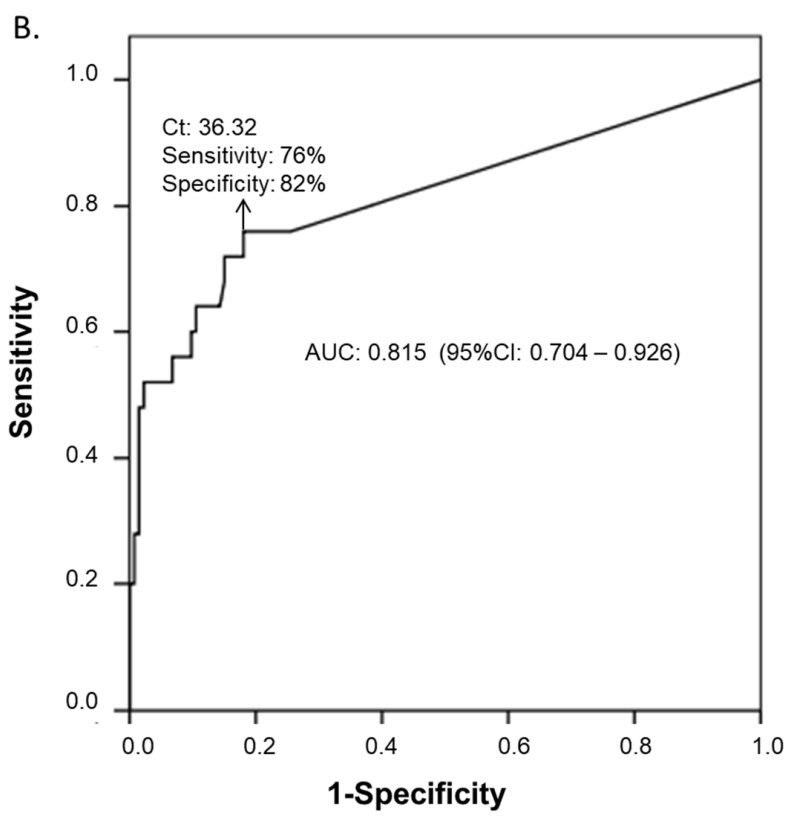

Figure 2. ROC curve analysis of the BAL and OW samples from immunosuppressed patients. With the arrow, the Ct value corresponding to the cut-off at which the best value of sensitivity and specificity for a diagnostic test is indicated when it is compared with BAL microscopy, according to sample type: (A) BAL; (B) OW. 
Table 2. Clinical and laboratory baseline features in all study groups.

\begin{tabular}{|c|c|c|c|}
\hline Characteristics & $\begin{array}{c}\text { Group 1: } \\
\text { Immunocompromised } \\
\text { Patients with Pneumonia } \\
\mathrm{n}=\mathbf{1 5 8}\end{array}$ & $\begin{array}{l}\text { Group 2: Individuals with } \\
\text { Lung Cancer } \\
\mathbf{n}=35\end{array}$ & $\begin{array}{c}\text { Group 3: Healthy } \\
\text { Individuals } \\
n=20\end{array}$ \\
\hline Male sex, n (\%) & $113(71.5)$ & $26 / 35(74.3)$ & $11(55)$ \\
\hline Age in years, median (IQR) & $37(29-45)$ & $63(58-70)$ & $39(21-50)$ \\
\hline Respiratory symptoms, n (\%) & & & 0 \\
\hline Cough & $118(75.2)$ & $24(70.6)$ & \\
\hline Dyspnea & $63(40.1)$ & $19(55.9)$ & \\
\hline Pleuritic pain & $27(17.2)$ & $6(17.6)$ & \\
\hline Hemoptysis & $14(8.9)$ & $9(26.5)$ & \\
\hline Fever $\geq 38^{\circ} \mathrm{C}$ & $121(77)$ & $13(38.2)$ & \\
\hline Pleural effusion & $24(15.3)$ & $14(41.2)$ & \\
\hline $\begin{array}{l}\text { Past medical history (clinical } \\
\text { condition at baseline), n (\%) }\end{array}$ & $158(100)$ & 0 & 0 \\
\hline AIDS & $126(79.7)$ & & \\
\hline CD4, cells $/ \mathrm{mm}^{3}$, median (IQR) & $53(16-126)$ & & \\
\hline CD4 < 200, cells $/ \mathrm{mm}^{3}, \mathrm{n}(\%)$ & $85(88.5)$ & & \\
\hline Transplanted & $22(13.9)$ & & \\
\hline Connective tissue disease & $5(3.2)$ & & \\
\hline Hematologic malignancies & $5(3.2)$ & & \\
\hline $\begin{array}{c}\text { Total leukocytes cell } / \mathrm{mm}^{3} \text {, } \\
\text { median (IQR) }\end{array}$ & $5760(3700-7800)$ & $11,860(8300-14,800)$ & \\
\hline PMN & 4117 (2300-6175) & $8449(5218-10,962)$ & \\
\hline Lymphocyte & $835(490-1460)$ & $2075(1540-2772)$ & \\
\hline Pulmonary lung infection & ** & 0 & $\mathrm{~N} / \mathrm{A}$ \\
\hline Pneumocystis jirovecii & $25(16)$ & & \\
\hline Mycobacterium tuberculosis & $30(19)$ & & \\
\hline Cryptococcus neoformans & $6(4)$ & & \\
\hline Histoplasma capsulatum & $4(2.5)$ & & \\
\hline Bacteria & $11(7)$ & & \\
\hline Unknown & $84(53)$ & & \\
\hline ICU admission & $24(15)$ & 0 & $\mathrm{~N} / \mathrm{A}$ \\
\hline In-hospital mortality & $18(11)$ & $1(2.9)$ & $\mathrm{N} / \mathrm{A}$ \\
\hline
\end{tabular}

** In group 1, there were 6 patients with mixed infection: 1 with $\mathrm{Pj}$ and M. tuberculosis infection, $1 \mathrm{Pj}+$ bacteria, 1 M. tuberculosis + bacteria, 1 H. capsulatum + C. neoformans, $1 \mathrm{Pj}+$ bacteria + M. tuberculosis, 1 M. tuberculosis + nontuberculous mycobacteria. N/A: Not applicable. IQR: Inter-quartile range.

This cut-off of 24.53 confirmed all of the microscopy-positive cases and identified three additional cases of PjP among the BAL of individuals from group 1. These three patients had a new HIV diagnosis, met the criteria of probable $\mathrm{PjP}$, and had individual $\mathrm{Ct}$ values of $16.05,16.66$, and 18.36. None of them died during the follow-up.

Among the Pj negative microscopy samples (133 patients), three patients were considered as probable $\mathrm{PjP}$ as previously mentioned, and among the 130 remaining patients of group 1, 66.2\% (86/130) were classified as colonized (Ct results between 25.03 and 36.99) (Figure 3A). 


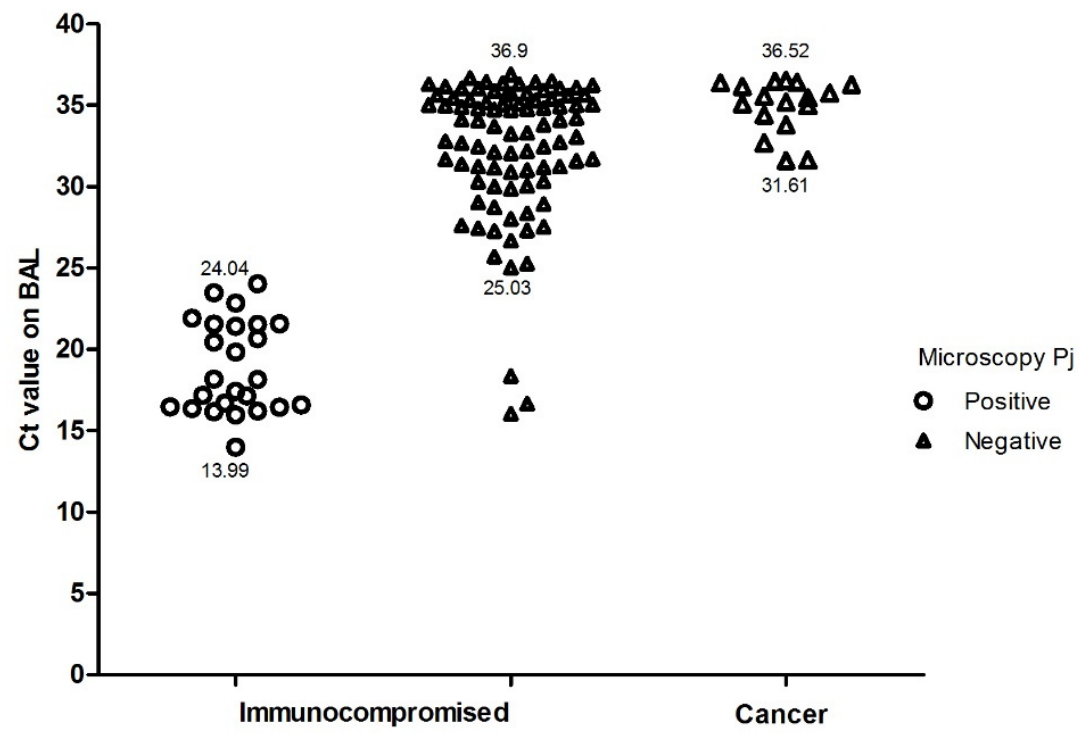

(A)

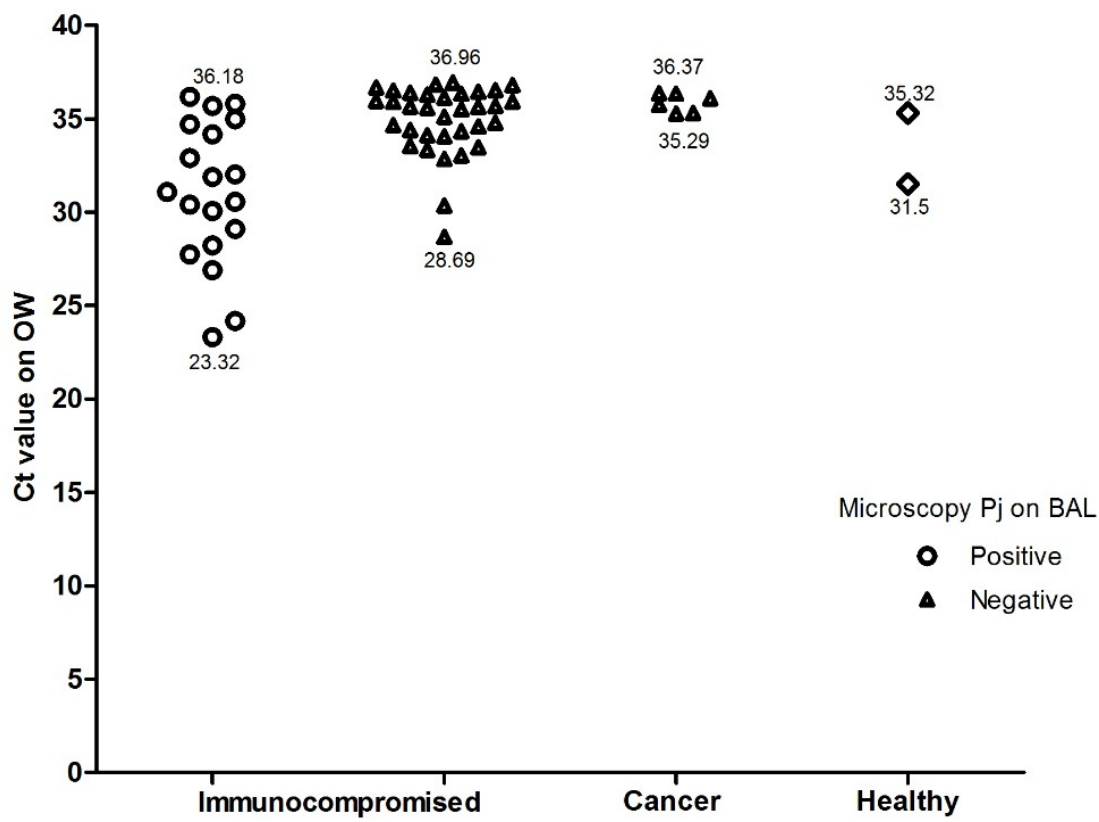

(B)

Figure 3. Ranges of the Ct values for the BAL (A) and OW (B) samples, according to microscopy results in the studied groups. The scatterplot shows $\mathrm{C} t$ values obtained in each respiratory sample according to the group and microscopy $\mathrm{Pj}$ results on BAL. In the healthy group, BAL was not performed. The numbers indicate the lower and upper $\mathrm{Ct}$ values.

No PjP cases were detected by microscopy or qPCR in the BAL samples of patients with lung cancer, but $48 \%$ of individuals were found to be colonized (Ct results between 31.61 and 36.52) (Figure 3B).

\subsection{Analysis of $q P C R$ in $O W$ Samples}

qPCR was positive in 53 of the $158 \mathrm{OW}$ samples from the immunocompromised patients, including 19 of the 25 microscopy-positive BAL samples (Figure 3B). The $\mathrm{Ct}$ values obtained from the $19 \mathrm{qPCR}$ and microscopy-positive patients were lower than the negative sample values (Me 31.08; IQR 28.66-34.44 vs. Me 35.61, IQR 34.12-36.30, 
respectively, $p \leq 0.001$ ), and as such, it was not possible to establish an acceptable cut-off for PjP diagnosis in the OW samples (AUC ROC: 0.815, 95\% CI 0.704 to 0.926) (Figure 2B). Nine of fifty-three patients were positive by qPCR in the OW sample, although none were positive in the BAL. The correlation between the $\mathrm{Ct}$ values of the BAL samples and those of the OW samples was low $(\rho=0.43, p \leq 0.001)$ (Figure 4$)$.

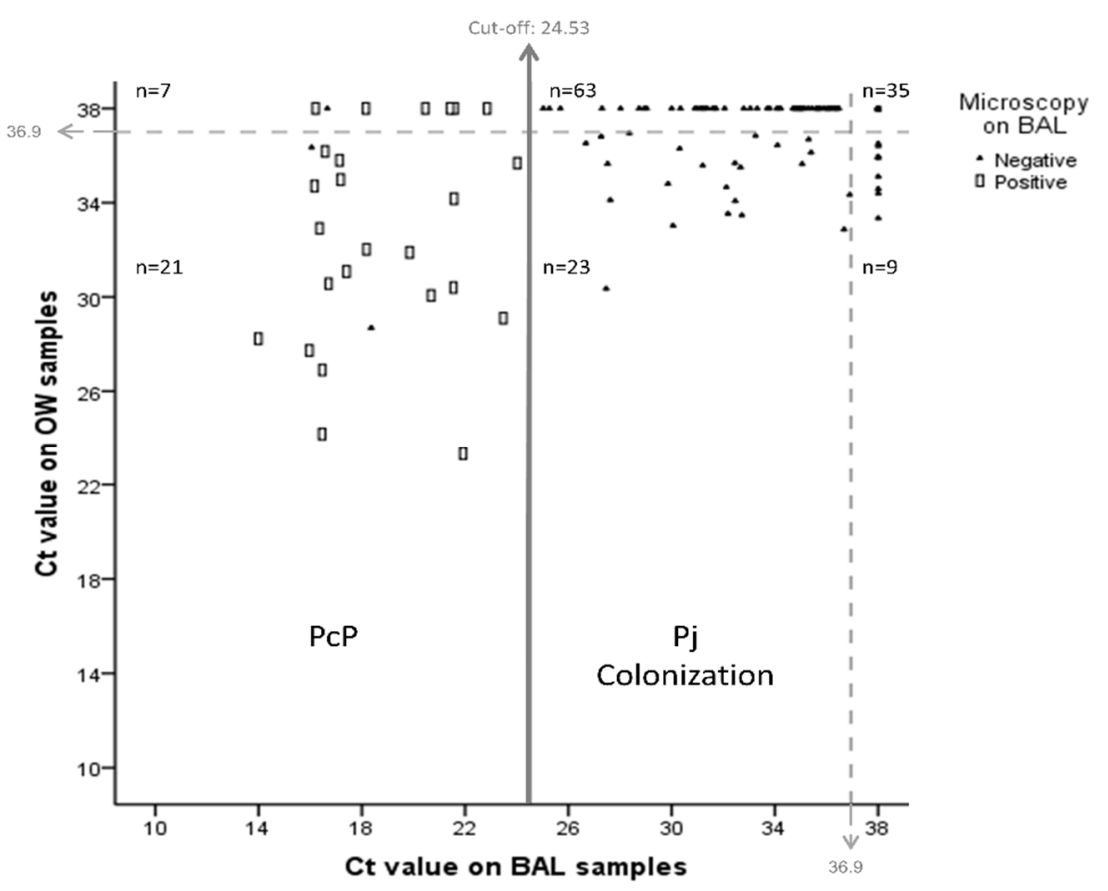

Figure 4. Scatterplot displaying the relationship between the Ct values for the BAL and OW samples in 158 patients. The continuous vertical line separates PjP disease from colonization, according to the cut-off established in BAL ( $c t=24.53$ ). Dashed lines indicate the maximum Ct value (36.9) above which qPCR was considered negative. In each case, the microscopy result for $P$. jirovecii is specified in the BAL samples ( $\square$ positive, $\Delta$ negative).

In the cancer patient group, 6 of the 35 patients' OW samples were qPCR-positive (17\%, Ct values between 35.29 and 36.37), including those from three patients who also had a positive BAL (Ct range 35.29-35.76). qPCR was positive in 2 (Ct 31.5 and 35.32) out of 20 healthy individuals in their OW samples (Figure 3B).

\subsection{Clinical Characteristics and Follow-Up of Immunosuppressed Patients, Colonized and Non-Infected Individuals}

AIDS, CD4 count less than 200 cells $/ \mathrm{mm}^{3}$, no prior history of prophylaxis with trimethoprim/sulfamethoxazole for $>12$ weeks, cough, dyspnea, pulsi oximetry $<90 \%$, tachypnea, tachycardia, interstitial opacities, and ground-glass pattern were more prevalent in people with PjP compared to non-infected individuals. History of corticosteroid was more prevalent in people colonized by Pj compared to non-infected individuals (Table 3).

Regarding clinical outcomes, $32.1 \%$ of people with PjP required ICU admission, compared to $12.9 \%$ of people colonized with $\mathrm{Pj}$ and $9.1 \%$ with those who were negative for $\mathrm{Pj}$. The in-hospital mortality was $14.3 \%$ in individuals with PjP, $11.6 \%$ in colonized individuals, and $9.1 \%$ in $\mathrm{Pj}$ negative individuals. People with $\mathrm{Pj}$ had higher mortality at 1 year of follow-up (39.3\%), and there was no difference between people who were colonized by $\mathrm{Pj}$ $(29.1 \%)$ and those who were Pj-negative $(27.3 \%)($ Long Rank test $=0.618)($ Figure 5). 
Table 3. Factors associated with Pneumocystis jirovecii (Pj) in 158 patients with severe immunosuppression with pneumonia.

\begin{tabular}{|c|c|c|c|c|c|c|}
\hline Characteristics & $\mathrm{PjPCt}<24.5 \mathrm{~N}=28$ & $\begin{array}{c}\text { Colonized Ct } 24.5-37 \\
\mathrm{~N}=86\end{array}$ & $\begin{array}{c}\text { Non-Infected } \mathrm{Ct}>37 \\
\mathrm{~N}=44\end{array}$ & $\begin{array}{l}\text { PjP vs. Colonized } \\
\text { Individuals * PR; } \\
\quad \text { (CI 95\%) }\end{array}$ & $\begin{array}{c}\text { PjP vs. } \\
\text { Non-Infected } \\
\text { Individuals ** PR; } \\
\text { (CI 95\%) }\end{array}$ & $\begin{array}{l}\text { Colonized vs. } \\
\text { Non-Infected } \\
\text { Individuals ** PR; } \\
(\text { CI } 95 \%)\end{array}$ \\
\hline \multicolumn{7}{|l|}{$\begin{array}{l}\text { Past medical history (clinical } \\
\text { condition at baseline) }\end{array}$} \\
\hline AIDS, $n(\%)$ & $27(96.4)$ & $64(74.4)$ & $35(79.5)$ & $6.82(0.98-47.62)$ & $1.212 ;(1.03-1.43)$ & $0.94 ;(0.77-1.14)$ \\
\hline Prior ART treatment, $n(\%)$ & $2 / 13(15.4)$ & $19 / 45(42.2)$ & $17 / 30(56.7)$ & $2.92(0.71-12.06)$ & $0.27 ;(0.07-1.01)$ & $0.74 ;(0.47-1.18)$ \\
\hline CD4 < 200, cells $/ \mathrm{mm}^{3}, n(\%)$ & $20 / 20(100)$ & $41 / 46(89.1)$ & $24 / 29(82.8)$ & $\mathrm{NE}$ & $1.21 ;(1.02-1.43)$ & $1.08 ;(0.89-1.31)$ \\
\hline HIV viral load $>50.000, n(\%)$ & $9 / 13(69.2)$ & $21 / 32(65.6)$ & $18 / 22(81.8)$ & $1.13(0.41-3.06)$ & $0.85 ;(0.56-1.28)$ & $0.80 ;(0.58-1.10)$ \\
\hline Transplanted, $n(\%)$ & $1(3.6)$ & $17(19.8)$ & $4(9.1)$ & $0.23(0.03-1.54)$ & $0.39 ;(0.05-3.34)$ & $2.17 ;(0.78-6.07)$ \\
\hline Hematologic malignancies, $n(\%)$ & 0 & $3(3.5)$ & $2(4.5)$ & NE & 0 & $0.77 ;(0.13-4.43)$ \\
\hline Systematic lupus erythematosus, $n(\%)$ & 0 & $2(2.3)$ & $3(6.8)$ & NE & 0 & $0.34 ;(0.06-1.97)$ \\
\hline Prior corticosteroid therapy $n / \mathrm{N}(\%)$ & $0 / 1$ & $5 / 18(27.8)$ & $4 / 5(80)$ & $0.18(0.02-1.27)$ & 0 & $0.35 ;(0.15-0.82)$ \\
\hline $\begin{array}{l}\text { No history of prophylaxis with } \\
\text { trimethoprim/sulfamethoxazole } \\
\text { for }>12 \text { weeks }\end{array}$ & $28 / 28(100)$ & $70 / 85(82.4)$ & $33 / 44(75)$ & NE & $1.33 ;(1.12-1.58)$ & $1.09 ;(0.91-1.34)$ \\
\hline \multicolumn{7}{|c|}{ Respiratory symptoms, $n(\%)$} \\
\hline Cough & $27 / 28(96.4)$ & $59 / 85(69.4)$ & $32 / 44(72.7)$ & $8.47 ;(1.20-59.49)$ & $1.33 ;(1.09-1.61)$ & $0.95 ;(0.76-1.20)$ \\
\hline Dyspnea & $24 / 28(85.7)$ & $26 / 85(30.6)$ & $13 / 44(29.5)$ & $7.56 ;(2.80-20.37)$ & $2.90 ;(1.79-4.69)$ & $1.03 ;(0.59-1.81)$ \\
\hline Pleuritic pain & $3 / 28(10.7)$ & $5 / 85(5.9)$ & $7 / 44(15.9)$ & $1.58 ;(0.60-4.10)$ & $0.67 ;(0.19-2.39)$ & $0.37 ;(0.12-1.10)$ \\
\hline Chest pain & $7 / 28(25)$ & $12 / 85(14.1)$ & $8 / 44(18.2)$ & $1.65 ;(0.82-3.32)$ & $1.38 ;(0.56-3.37)$ & $0.78 ;(0.34-1.76)$ \\
\hline Hemoptysis & $1 / 28(3.6)$ & $7 / 85(8.2)$ & $6 / 44(13.6)$ & $0.49 ;(0.08-3.13)$ & $0.26 ;(0.03-2.06)$ & $0.60 ;(0.22-1.69)$ \\
\hline Fever $\geq 38^{\circ} \mathrm{C}$ & $23 / 28(82.1)$ & $65 / 85(76.5)$ & $33 / 44(75)$ & $1.31 ;(0.55-3.09)$ & $1.09 ;(0.86-1.39)$ & $1.02 ;(0.83-1.26)$ \\
\hline Pulse oximetry $<90$ & $12 / 21(57.1)$ & $8 / 60(13.3)$ & $6 / 30(20)$ & $4.07 ;(2.02-8.2)$ & $2.85 ;(1.28-6.39)$ & $0.67 ;(0.25-1.75)$ \\
\hline
\end{tabular}


Table 3. Cont

\begin{tabular}{|c|c|c|c|c|c|c|}
\hline Characteristics & $\mathrm{PjPCt}<24.5 \mathrm{~N}=28$ & $\begin{array}{l}\text { Colonized Ct } 24.5-37 \\
\qquad N=86\end{array}$ & $\begin{array}{c}\text { Non-Infected Ct }>37 \\
\qquad N=44\end{array}$ & $\begin{array}{l}\text { PjP vs. Colonized } \\
\text { Individuals * PR; } \\
\text { (CI 95\%) }\end{array}$ & $\begin{array}{c}\text { PjP vs. } \\
\text { Non-Infected } \\
\text { Individuals ** PR; } \\
\text { (CI 95\%) }\end{array}$ & $\begin{array}{c}\text { Colonized vs. } \\
\text { Non-Infected } \\
\text { Individuals ** PR; } \\
\text { (CI 95\%) }\end{array}$ \\
\hline Tachycardia & $17 / 28(60.7)$ & $31 / 85(36.5)$ & $13 / 44(70.6)$ & $2.09 ;(1.08-4.05)$ & $2.05 ;(1.19-3.54)$ & $1.23 ;(0.72-2.11)$ \\
\hline Lymphocytes $<750$ cells $/ \mathrm{mm}^{3}$ & $15 / 28(53.6)$ & $39 / 84(46.4)$ & $15 / 44(34.1)$ & $1.239(0.65-2.36)$ & $1.57 ;(0.91-2.69)$ & $1.36 ;(0.85-2.18)$ \\
\hline $\mathrm{LDH}>450 \mathrm{UI} / \mathrm{L}(\mathrm{n}=118)$ & $16 / 24(66.7)$ & $19 / 62(30.6)$ & $10 / 32(31.2)$ & $2.91(1.40-6.06)$ & $2.13 ;(1.19-3.84)$ & $0.98 ;(0.52-1.85)$ \\
\hline \multicolumn{7}{|c|}{ Radiographic features, $n(\%)$} \\
\hline Normal radiographic & $4 / 28(14.3)$ & 26/81 (32.1) & $12 / 44(27.3)$ & $0.44 ;(0.166-1.16)$ & $0.53 ;(0.188-1.46)$ & $1.18 ;(0.66-2.10)$ \\
\hline Interstitial opacities & $23 / 28(82.1)$ & $39 / 81(48.2)$ & $21 / 44(47.7)$ & $3.49 ;(1.43-8.49)$ & $1.72 ;(1.21-2.45)$ & $1.01 ;(0.69-1.48)$ \\
\hline Pleural effusion & $2 / 28(7.1)$ & $15 / 85(17.6)$ & $7 / 44(15.9)$ & $0.43 ;(0.11-1.66)$ & $0.45 ;(0.10-2.01)$ & $1.11 ;(0.49-2.52)$ \\
\hline Ground-glass pattern & $13 / 16(81.3)$ & $11 / 53(20.8)$ & $5 / 31(16.1)$ & $8.13 ;(2.56-25.75)$ & $5.04 ;(2.18-11.63)$ & $1.29 ;(0.49-3.36)$ \\
\hline \multicolumn{7}{|c|}{ Complications and clinical outcomes } \\
\hline Acute respiratory distress syndrome & $9 / 28(32.1)$ & $7 / 85(8.2)$ & $2 / 44((4.6)$ & $2.87 ;(1.59-5.19)$ & $7.07 ;(1.65-30.36)$ & $1.81 ;(0.39-8.36)$ \\
\hline Pneumothorax & $0 / 28(0)$ & 2/85 (2.4) & $1 / 44(2.3)$ & NE & 0 & $1.04 ;(0.09-11.11)$ \\
\hline ICU admission & $9 / 28(32.1)$ & $11 / 85(12.9)$ & $4 / 44(9.1)$ & $2.20 ;(1.17-1.13)$ & $3.54 ;(1.20-10.39)$ & $1.42 ;(0.48-4.213)$ \\
\hline Mechanical ventilation required & $6 / 28(21.4)$ & 10/85 (11.8) & $4 / 44(9.1)$ & $2.20 ;(1.17-4.13)$ & $2.36 ;(0.73-7.62)$ & $1.29 ;(0.43-3.89)$ \\
\hline In-hospital mortality & $4 / 28(14.3)$ & $10 / 86(11.6)$ & $4 / 44(9.1)$ & $1.19(0.49-2.92)$ & $1.57 ;(0.43-5.78)$ & $1.28 ;(0.43-3.85)$ \\
\hline
\end{tabular}

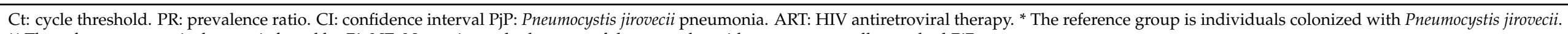

** The reference group is the non-infected by Pj. NE: Not estimated when one of the group has either no cases or all cases had PjP. 


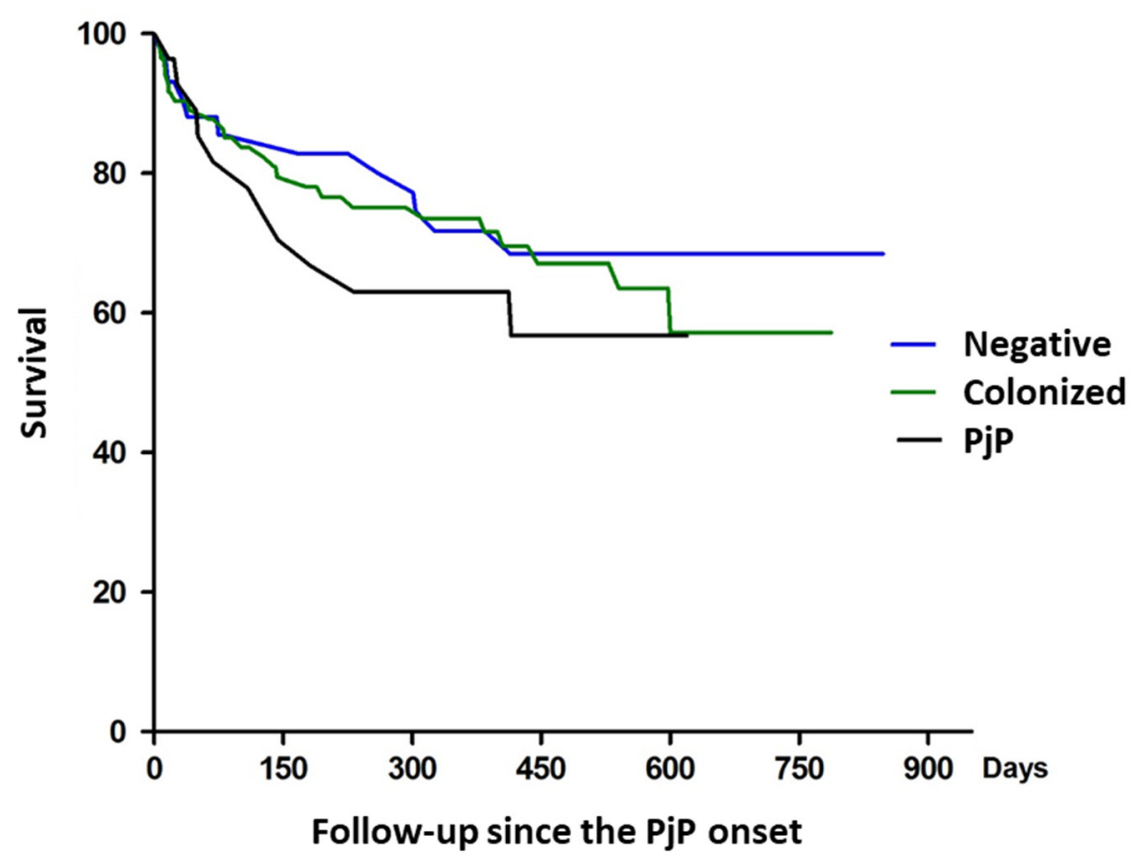

Figure 5. Survival of people with severe immunosuppression (28 with Pneumocystis jirovecii pneumonia (PjP), 86 colonized by $\mathrm{Pj}$ and 44 non-infected by $\mathrm{Pj}$ ) at 1 year of follow-up.

\section{Discussion}

Using our qPCR protocol and the threshold established herein, we were able to diagnose PjP and to discriminate between PjP and colonization in BAL samples of prospectively recruited patients with severe immunosuppression. In addition, we found that OW samples were not a useful sample type for discriminating between PjP and colonization, and we did not detect all PjP identified by TBO and DFA in BAL.

To date, we found 31 articles in PubMed that established a cut-off for molecular diagnosis of Pj using qPCR. Among them, 19 were retrospective $[4,14,16,19,20,22,23,26,42-51]$, 9 were prospective $[13,15,18,21,23-25,52,53]$, and 3 were mixed [12,54,55]. In 26 of them, authors accepted the diagnosis of $\mathrm{PjP}$ when one or more of the following criteria were present: clinical presentation suggestive of $\mathrm{PjP}$, adequate response to $\mathrm{PjP}$ treatment, lung images suggestive of pneumonia caused by $\mathrm{Pj}$, and/or a microscopy-positive $\mathrm{Pj}$ sample. Given that all patients were severely immunosuppressed and were at a higher risk for having one or more opportunistic infections, that there are no pathognomonic clinical or radiological presentations of $\mathrm{PjP}$, and that an equivalent therapeutic response can be observed in pneumonia caused by other microorganisms, it is necessary to use microscopy to definitively diagnose PjP. However, despite these aforementioned points, only five studies used microscopy to reach their diagnoses $[4,13,24,43,50]$.

Of the five studies, three were retrospective and two were prospective, and all of the populations were immunosuppressed (albeit due to different etiologies). Only two studies used ROC curves to establish a cut-off $[13,24]$. Fillaux et al. amplified the multicopy gene MSG from 400 fresh BAL samples, and established a Ct cut-off value of $<22$ as positive for $\mathrm{Pj}$ and $>28$ as negative, while those between this range were identified as indeterminant [24]. Conversely, Moodley et al., used the same mtLSU gene that was used in our study; however, they targeted a different region of the gene and established a different cut-off value $(\mathrm{Ct}$ 38.19). In their study, they evaluated 305 patients using $\mathrm{Pj}$ immunofluorescence and found 156 positives, 138 negatives, and 11 indeterminant cases. When they compared those results with qPCR, they found that qPCR detected 204 positive cases ( 41 false positives) and 101 negatives (4 false negatives), and had an AUC of ROC curve of 0.92 [13]. However, the results of Moodley et al. cannot be directly compared to the study herein since their 
patients had a different type of immunosuppression, the qPCR technique amplified a different region of $\mathrm{mtLSU}$, and they used a probe-based detection protocol.

Overall, these studies highlight the heterogeneity of previously published results, and therefore, the difficulties associated with diagnosing Pj infections using molecular techniques. Consequently, our study, which identifies a new qPCR that allows differentiation between colonization and infection with high sensitivity and specificity $(>98 \%$ for both) in prospectively recruited patients, will serve as a stepping stone for developing a Pj diagnostic procedure that reflects current clinical practice, and should be evaluated in other studies and populations.

As previously mentioned, our qPCR detected 28/158 PjP cases in group 1 , which was $10.7 \%$ more than microscopy alone. Since PJP diagnosis traditionally relies on visualization of the organism in respiratory samples, the three additional cases detected using our qPCR method could have been misinterpreted as PJP colonization had other PCR assays been used. However, in our study, we considered these cases to be PjP due to their new HIV diagnosis, their high fungal load, and the clinical diagnosis of $\mathrm{PjP}$, including that the patient improved with treatment dose of $\mathrm{Pj} \mathrm{P}$, with no other microbiological diagnosis that explained the cause of pneumonia, and these three patients were alive during the 1-year follow-up. This divergence from the microscopy findings may be attributed to the presence of co-infections, as two of the samples were also infected with Mycobacterium avium complex, a factor that could affect $\mathrm{Pj}$ visualization [56].

Furthermore, qPCR identified 86 cases of Pj colonization (54\%) among our patient groups, all of which were from immunosuppressed individuals who had had respiratory symptoms, and were negative by microscopy. These findings match those observed previously in Pereira RM et al., which found Pj colonization rates of $44 \%$ among HIVpositive Brazilian participants with no respiratory symptoms. Moreover, they found that the lower the CD4 count, the higher the percentage of colonization [57].

Our cut-off point could also be validated in group 2, where $48 \%$ of patients with lung cancer $(\mathrm{n}=17)$ had $\mathrm{Ct}$ values within the range of colonization, a finding which is consistent with that currently reported in literature (i.e., between $20-100 \%$ according to the patient's clinical condition) $[8,28]$.

Currently, it is unknown whether $\mathrm{Pj}$ colonization contributes to pneumonia development by itself or if it does so with other respiratory pathogens. Additionally, our understanding of how $\mathrm{Pj}$ interacts with other microorganisms, or under which conditions a colonized subject can become infectious, is incomplete. Therefore, it is necessary to conduct cohort studies supported by molecular epidemiological tools to evaluate these aspects, which could help increase our understanding regarding the role of $\mathrm{Pj}$ as a colonizer $[18,27,58]$.

Regarding the OW samples, we were unable to establish a threshold to differentiate between disease and colonization; however, we were able to detect Pj. Additionally, OW $\mathrm{Ct}$ values had a low correlation with the $\mathrm{Pj} \mathrm{Ct}$ values seen in BAL samples. It has been reported that during respiratory infections, there are discrepancies between respiratory samples [59-61], not only because of the dynamic of the infection, but also because respiratory samples are not homogeneous matrices due to the presence of mucus. As Pj often only passes transiently through the upper respiratory tract and replicates within the alveolar space, this finding was to be expected. In the OW samples, we found that $10 \%$ of the healthy individuals were colonized with $\mathrm{Pj}$, a rate which has been reported previously in studies using nested PCR amplifying for the $m t L S U r R N A$ gene [31,62-64]. Pj could also be a transient colonizer in the upper airway, as we previously reported in newborns and their mothers [65].

The main limitation of this study was that we could not establish a cut-off for people with severe immunosuppression that are non-HIV-positive, as suggested by previous researchers, because most of our patients were people living with HIV. 


\section{Conclusions}

The qPCR threshold established herein allowed for reliable diagnosis of PjP and differentiation between $\mathrm{PjP}$ disease and colonization in BAL of immunocompromised patients with pneumonia. In contrast, $\mathrm{OW}$ samples were not useful in distinguishing between disease and colonization. Our qPCR should be evaluated in other populations to validate our findings.

Author Contributions: Conceptualization, Y.A.A., Z.V.R., C.M., L.A.V.; Data acquisition, Z.V.R., M.A.M., Y.A.A.; Sample processing, Y.A.A., C.V., J.R.; Analysis and interpretation of data, all authors; Writing—original draft, Y.A.A., Z.V.R., L.A.V.; Writing—review and editing, all authors; Supervision, L.A.V.; Project administration, Y.A.A., Z.V.R.; Funding acquisition, L.A.V. All authors agree to be held accountable for all aspects of the work in ensuring that questions related to the accuracy or integrity of any part of the work are appropriately investigated and resolved. All authors have read and agreed to the published version of the manuscript.

Funding: This research was funded by Colciencias (Currently, Minciencias, Administrative Department of Science, Technology and Innovation) and Universidad de Antioquia (grant no. 111534319142), Fundación Investigando en Salud y Enfermedades Infecciosas, and the Universidad de Antioquia, through the Estrategia de Sostenibilidad. Y.A.A. was awarded with a Ph.D. scholarship from Minciencias (Programa de Doctorado Nacional año 2008). The funders had no role in the study design, data collection and analysis, decision to publish the results, or preparation of the manuscript. The open access fee of this paper was paid by Universidad Pontificia Bolivariana, Universidad de Antioquia and Asociación Colombiana de Infectología, Capítulo Antioquia.

Institutional Review Board Statement: The study was conducted according to the guidelines of the Declaration of Helsinki, and approved by the Ethics Committees of the School of Medicine (Comité de Ética del Centro de Investigaciones de la Facultad de Medicina) (10 May 2006, no. 003) at the University of Antioquia; from the Unidad de Investigaciones del Hospital Universitario San Vicente de Paul (25 June 2007); and from the Comité de Investigación Clínica ESE Hospital La María (31 May 2007). All study participants provided written informed consent.

Informed Consent Statement: Informed consent was obtained from all subjects involved in the study.

Data Availability Statement: The database is available upon request.

Acknowledgments: We want to thank all patients who agreed to participate in the study and the institutions from which the patients were recruited: Hospital Universitario San Vicente Fundación and Hospital La María. We would also like to thank the Corporación para Investigaciones Biológicas, the School of Microbiology, and the School of Medicine from the Universidad de Antioquia for providing clinical isolates of bacteria and fungi for the qPCR analytical specificity assays. We would also like to thank Diego Castaño, Santiago Giraldo, Antonio Macias, and Diana Moncada for their help in patient recruitment, as well as all the pulmonologists who took the BAL samples.

Conflicts of Interest: The authors declare no conflict of interest. The funders had no role in the design of the study; in the collection, analyses, or interpretation of data; in the writing of the manuscript, or in the decision to publish the results.

\section{References}

1. Tellez, I.; Barragán, M.; Franco-Paredes, C.; Petraro, P.; Nelson, K.; Del Rio, C. Pneumocystis Jiroveci Pneumonia in Patients with AIDS in the Inner City: A Persistent and Deadly Opportunistic Infection. Am. J. Med. Sci. 2008, 335, 192-197. [CrossRef] [PubMed]

2. Sattler, F.R.; Cowan, R.; Nielsen, D.M.; Ruskin, J. Trimethoprim-Sulfamethoxazole Compared with Pentamidine for Treatment of Pneumocystis Carinii Pneumonia in the Acquired Immunodeficiency Syndrome. A Prospective, Noncrossover Study. Ann. Intern. Med. 1988, 109, 280-287. [CrossRef] [PubMed]

3. Rath, P.-M.; Steinmann, J. Update on Diagnosis of Pneumocystis Pulmonary Infections. Curr. Fungal Infect. Rep. 2014, 8, 227-234. [CrossRef]

4. Larsen, H.H.; Masur, H.; Kovacs, J.A.; Gill, V.J.; Silcott, V.A.; Kogulan, P.; Maenza, J.; Smith, M.; Lucey, D.R.; Fischer, S.H. Development and Evaluation of a Quantitative, Touch-down, Real-Time PCR Assay for Diagnosing Pneumocystis Carinii Pneumonia. J. Clin. Microbiol. 2002, 40, 490-494. [CrossRef] 
5. Larsen, H.H.; Huang, L.; Kovacs, J.A.; Crothers, K.; Silcott, V.A.; Morris, A.; Turner, J.R.; Beard, C.B.; Masur, H.; Fischer, S.H. A Prospective, Blinded Study of Quantitative Touch-down Polymerase Chain Reaction Using Oral-Wash Samples for Diagnosis of Pneumocystis Pneumonia in HIV-Infected Patients. J. Infect. Dis. 2004, 189, 1679-1683. [CrossRef]

6. Hviid, C.J.; Lund, M.; Sørensen, A.; Ellermann-Eriksen, S.; Jespersen, B.; Dam, M.Y.; Dahlerup, J.F.; Benfield, T.; Jespersen, S.; Østergaard, L.J.; et al. Detection of Pneumocystis Jirovecii in Oral Wash from Immunosuppressed Patients as a Diagnostic Tool. PLoS ONE 2017, 12, e0174012. [CrossRef]

7. Sing, A.; Roggenkamp, A.; Autenrieth, I.B.; Heesemann, J. Pneumocystis Carinii Carriage in Immunocompetent Patients with Primary Pulmonary Disorders as Detected by Single or Nested PCR. J. Clin. Microbiol. 1999, 37, 3409-3410. [CrossRef] [PubMed]

8. Maskell, N.A.; Waine, D.J.; Lindley, A.; Pepperell, J.C.T.; Wakefield, A.E.; Miller, R.F.; Davies, R.J.O. Asymptomatic Carriage of Pneumocystis Jiroveci in Subjects Undergoing Bronchoscopy: A Prospective Study. Thorax 2003, 58, 594-597. [CrossRef]

9. Totet, A.; Meliani, L.; Lacube, P.; Pautard, J.C.; Raccurt, C.; Roux, P.; Nevez, G. Immunocompetent Infants as a Human Reservoir for Pneumocystis Jirovecii: Rapid Screening by Non-Invasive Sampling and Real-Time PCR at the Mitochondrial Large Subunit RRNA Gene. J. Eukaryot. Microbiol. 2003, 50, 668-669. [CrossRef]

10. Qu, J.; Rong, Z.; He, L.; Pan, J.; Chen, X. Relationship between the Burden of Pneumocystis Carinii, the Inflammatory Reaction and Lung Injury in Pneumocystis Carinii Pneumonia. Chin. Med. J. 2000, 113, 1071-1074. [PubMed]

11. Thomas, C.F.; Limper, A.H. Current Insights into the Biology and Pathogenesis of Pneumocystis Pneumonia. Nat. Rev. Microbiol. 2007, 5, 298-308. [CrossRef]

12. Hoarau, G.; Le Gal, S.; Zunic, P.; Poubeau, P.; Antok, E.; Jaubert, J.; Nevez, G.; Picot, S. Evaluation of Quantitative FTDPneumocystis Jirovecii Kit for Pneumocystis Infection Diagnosis. Diagn. Microbiol. Infect. Dis. 2017, 89, 212-217. [CrossRef] [PubMed]

13. Moodley, B.; Tempia, S.; Frean, J.A. Comparison of Quantitative Real-Time PCR and Direct Immunofluorescence for the Detection of Pneumocystis Jirovecii. PLoS ONE 2017, 12, e0180589. [CrossRef]

14. Unnewehr, M.; Friederichs, H.; Bartsch, P.; Schaaf, B. High Diagnostic Value of a New Real-Time Pneumocystis PCR from Bronchoalveolar Lavage in a Real-Life Clinical Setting. Respiration 2016, 92, 144-149. [CrossRef]

15. Fauchier, T.; Hasseine, L.; Gari-Toussaint, M.; Casanova, V.; Marty, P.M.; Pomares, C. Detection of Pneumocystis Jirovecii by Quantitative PCR To Differentiate Colonization and Pneumonia in Immunocompromised HIV-Positive and HIV-Negative Patients. J. Clin. Microbiol. 2016, 54, 1487-1495. [CrossRef] [PubMed]

16. Louis, M.; Guitard, J.; Jodar, M.; Ancelle, T.; Magne, D.; Lascols, O.; Hennequin, C. Impact of HIV Infection Status on Interpretation of Quantitative PCR for Detection of Pneumocystis Jirovecii. J. Clin. Microbiol. 2015, 53, 3870-3875. [CrossRef]

17. Montesinos, I.; Brancart, F.; Schepers, K.; Jacobs, F.; Denis, O.; Delforge, M.-L. Comparison of 2 Real-Time PCR Assays for Diagnosis of Pneumocystis Jirovecii Pneumonia in Human Immunodeficiency Virus (HIV) and Non-HIV Immunocompromised Patients. Diagn. Microbiol. Infect. Dis. 2015, 82, 143-147. [CrossRef] [PubMed]

18. Robert-Gangneux, F.; Belaz, S.; Revest, M.; Tattevin, P.; Jouneau, S.; Decaux, O.; Chevrier, S.; Le Tulzo, Y.; Gangneux, J.-P. Diagnosis of Pneumocystis Jirovecii Pneumonia in Immunocompromised Patients by Real-Time PCR: A 4-Year Prospective Study. J. Clin. Microbiol. 2014, 52, 3370-3376. [CrossRef]

19. Maillet, M.; Maubon, D.; Brion, J.P.; François, P.; Molina, L.; Stahl, J.P.; Epaulard, O.; Bosseray, A.; Pavese, P. Pneumocystis Jirovecii (Pj) Quantitative PCR to Differentiate Pj Pneumonia from Pj Colonization in Immunocompromised Patients. Eur. J. Clin. Microbiol. Infect. Dis. 2014, 33, 331-336. [CrossRef]

20. Damiani, C.; Le Gal, S.; Da Costa, C.; Virmaux, M.; Nevez, G.; Totet, A. Combined Quantification of Pulmonary Pneumocystis Jirovecii DNA and Serum (1->3)- $\beta$-D-Glucan for Differential Diagnosis of Pneumocystis Pneumonia and Pneumocystis Colonization. J. Clin. Microbiol. 2013, 51, 3380-3388. [CrossRef]

21. Matsumura, Y.; Ito, Y.; Iinuma, Y.; Yasuma, K.; Yamamoto, M.; Matsushima, A.; Nagao, M.; Takakura, S.; Ichiyama, S. Quantitative Real-Time PCR and the $(1 \rightarrow 3)-\beta$-D-Glucan Assay for Differentiation between Pneumocystis Jirovecii Pneumonia and Colonization. Clin. Microbiol. Infect. 2012, 18, 591-597. [CrossRef] [PubMed]

22. Mühlethaler, K.; Bögli-Stuber, K.; Wasmer, S.; von Garnier, C.; Dumont, P.; Rauch, A.; Mühlemann, K.; Garzoni, C. Quantitative PCR to Diagnose Pneumocystis Pneumonia in Immunocompromised Non-HIV Patients. Eur. Respir. J. 2012, 39, 971-978. [CrossRef] [PubMed]

23. Alanio, A.; Desoubeaux, G.; Sarfati, C.; Hamane, S.; Bergeron, A.; Azoulay, E.; Molina, J.M.; Derouin, F.; Menotti, J. RealTime PCR Assay-Based Strategy for Differentiation between Active Pneumocystis Jirovecii Pneumonia and Colonization in Immunocompromised Patients. Clin. Microbiol. Infect. 2011, 17, 1531-1537. [CrossRef] [PubMed]

24. Fillaux, J.; Malvy, S.; Alvarez, M.; Fabre, R.; Cassaing, S.; Marchou, B.; Linas, M.-D.; Berry, A. Accuracy of a Routine Real-Time PCR Assay for the Diagnosis of Pneumocystis Jirovecii Pneumonia. J. Microbiol. Methods 2008, 75, 258-261. [CrossRef]

25. Flori, P.; Bellete, B.; Durand, F.; Raberin, H.; Cazorla, C.; Hafid, J.; Lucht, F.; Sung, R.T.M. Comparison between Real-Time PCR, Conventional PCR and Different Staining Techniques for Diagnosing Pneumocystis Jiroveci Pneumonia from Bronchoalveolar Lavage Specimens. J. Med. Microbiol. 2004, 53, 603-607. [CrossRef] [PubMed]

26. Church, D.L.; Ambasta, A.; Wilmer, A.; Williscroft, H.; Ritchie, G.; Pillai, D.R.; Champagne, S.; Gregson, D.G. Development and Validation of a Pneumocystis Jirovecii Real-Time Polymerase Chain Reaction Assay for Diagnosis of Pneumocystis Pneumonia. Can. J. Infect. Dis. Med. Microbiol. 2015, 26, 263-267. [CrossRef] [PubMed] 
27. Morris, A.; Wei, K.; Afshar, K.; Huang, L. Epidemiology and Clinical Significance of Pneumocystis Colonization. J. Infect. Dis. 2008, 197, 10-17. [CrossRef]

28. De la Horra, C.; Varela, J.M.; Fernández-Alonso, J.; Medrano, F.J.; Respaldiza, N.; Montes-Cano, M.A.; Calderón, E.J. Association between Human-Pneumocystis Infection and Small-Cell Lung Carcinoma. Eur. J. Clin. Investig. 2004, 34, 229-235. [CrossRef]

29. Nevez, G.; Magois, E.; Duwat, H.; Gouilleux, V.; Jounieaux, V.; Totet, A. Apparent Absence of Pneumocystis Jirovecii in Healthy Subjects. Clin. Infect. Dis. 2006, 42, e99-e101. [CrossRef]

30. Mori, S.; Cho, I.; Sugimoto, M. A Followup Study of Asymptomatic Carriers of Pneumocystis Jiroveci during Immunosuppressive Therapy for Rheumatoid Arthritis. J. Rheumatol. 2009, 36, 1600-1605. [CrossRef]

31. Vargas, S.L.; Pizarro, P.; López-Vieyra, M.; Neira-Avilés, P.; Bustamante, R.; Ponce, C.A. Pneumocystis Colonization in Older Adults and Diagnostic Yield of Single versus Paired Noninvasive Respiratory Sampling. Clin. Infect. Dis. 2010, 50, e19-e21. [CrossRef]

32. Miller, R.F.; Ambrose, H.E.; Wakefield, A.E. Pneumocystis Carinii f. Sp. Hominis DNA in Immunocompetent Health Care Workers in Contact with Patients with P. Carinii Pneumonia. J. Clin. Microbiol. 2001, 39, 3877-3882. [CrossRef]

33. Vélez, L.; Correa, L.T.; Maya, M.A.; Mejía, P.; Ortega, J.; Bedoya, V.; Ortega, H. Diagnostic Accuracy of Bronchoalveolar Lavage Samples in Immunosuppressed Patients with Suspected Pneumonia: Analysis of a Protocol. Respir. Med. 2007, 101, $2160-2167$. [CrossRef]

34. Helweg-Larsen, J.; Jensen, J.S.; Benfield, T.; Svendsen, U.G.; Lundgren, J.D.; Lundgren, B. Diagnostic Use of PCR for Detection of Pneumocystis Carinii in Oral Wash Samples. J. Clin. Microbiol. 1998, 36, 2068-2072. [CrossRef] [PubMed]

35. Rodiño, J.; Rincón, N.; Aguilar, Y.A.; Rueda, Z.V.; Herrera, M.; Vélez, L.A. [Microscopic diagnosis of Pneumocystis jirovecii pneumonia in bronchoalveolar lavage and oropharyngeal wash samples of immunocompromised patients with pneumonia]. Biomedica 2011, 31, 222-231. [CrossRef]

36. Robberts, F.J.L.; Liebowitz, L.D.; Chalkley, L.J. Polymerase Chain Reaction Detection of Pneumocystis Jiroveci: Evaluation of 9 Assays. Diagn. Microbiol. Infect. Dis. 2007, 58, 385-392. [CrossRef]

37. Ruijter, J.M.; Ramakers, C.; Hoogaars, W.M.H.; Karlen, Y.; Bakker, O.; van den Hoff, M.J.B.; Moorman, A.F.M. Amplification Efficiency: Linking Baseline and Bias in the Analysis of Quantitative PCR Data. Nucleic Acids Res. 2009, 37, e45. [CrossRef] [PubMed]

38. MM19A: Molecular Testing in Clinical Lab Environments. Available online: https:/ /clsi.org/standards/products / moleculardiagnostics/documents/mm19/ (accessed on 5 November 2021).

39. MM06A2E: Quantitative Molecular Methods for Diseases. Available online: https:/ / clsi.org/standards/products / moleculardiagnostics/documents/mm06/ (accessed on 5 November 2021).

40. MM03Ed3: Molecular Diagnostic Methods for Diseases. Available online: https://clsi.org/standards/products/moleculardiagnostics/documents/mm03/ (accessed on 5 November 2021).

41. Singh, J. International Conference on Harmonization of Technical Requirements for Registration of Pharmaceuticals for Human Use. J. Pharmacol. Pharmacother. 2015, 6, 185-187. [CrossRef]

42. Montesinos, I.; Delforge, M.-L.; Ajjaham, F.; Brancart, F.; Hites, M.; Jacobs, F.; Denis, O. Evaluation of a New Commercial Real-Time PCR Assay for Diagnosis of Pneumocystis Jirovecii Pneumonia and Identification of Dihydropteroate Synthase (DHPS) Mutations. Diagn. Microbiol. Infect. Dis. 2017, 87, 32-36. [CrossRef]

43. Botterel, F.; Cabaret, O.; Foulet, F.; Cordonnier, C.; Costa, J.-M.; Bretagne, S. Clinical Significance of Quantifying Pneumocystis Jirovecii DNA by Using Real-Time PCR in Bronchoalveolar Lavage Fluid from Immunocompromised Patients. J. Clin. Microbiol. 2012, 50, 227-231. [CrossRef] [PubMed]

44. Rudramurthy, S.M.; Sharma, M.; Sharma, M.; Rawat, P.; Ghosh, A.; Venkatesan, L.; Aggarwal, R.; Singh, M.; Chakrabarti, A. Reliable Differentiation of Pneumocystis Pneumonia from Pneumocystis Colonisation by Quantification of Major Surface Glycoprotein Gene Using Real-Time Polymerase Chain Reaction. Mycoses 2018, 61, 96-103. [CrossRef]

45. Fujisawa, T.; Suda, T.; Matsuda, H.; Inui, N.; Nakamura, Y.; Sato, J.; Toyoshima, M.; Nakano, Y.; Yasuda, K.; Gemma, H.; et al. Real-Time PCR Is More Specific than Conventional PCR for Induced Sputum Diagnosis of Pneumocystis Pneumonia in Immunocompromised Patients without HIV Infection. Respirology 2009, 14, 203-209. [CrossRef]

46. Rohner, P.; Jacomo, V.; Studer, R.; Schrenzel, J.; Graf, J.-D. Detection of Pneumocystis Jirovecii by Two Staining Methods and Two Quantitative PCR Assays. Infection 2009, 37, 261-265. [CrossRef]

47. Orsi, C.F.; Bettua, C.; Pini, P.; Venturelli, C.; La Regina, A.; Morace, G.; Luppi, M.; Forghieri, F.; Bigliardi, S.; Luppi, F.; et al. Detection of Pneumocystis Jirovecii and Aspergillus Spp. DNa in Bronchoalveolar Lavage Fluids by Commercial Real-Time PCr Assays: Comparison with Conventional Diagnostic Tests. New Microbiol. 2015, 38, 75-84. [PubMed]

48. Orsi, C.F.; Gennari, W.; Venturelli, C.; La Regina, A.; Pecorari, M.; Righi, E.; Machetti, M.; Blasi, E. Performance of 2 Commercial Real-Time Polymerase Chain Reaction Assays for the Detection of Aspergillus and Pneumocystis DNA in Bronchoalveolar Lavage Fluid Samples from Critical Care Patients. Diagn. Microbiol. Infect. Dis. 2012, 73, 138-143. [CrossRef]

49. Issa, N.; Gabriel, F.; Baulier, G.; Mourissoux, G.; Accoceberry, I.; Guisset, O.; Camou, F. Pneumocystosis and Quantitative PCR. Med. Mal. Infect. 2018, 48, 474-480. [CrossRef] [PubMed]

50. Bandt, D.; Monecke, S. Development and Evaluation of a Real-Time PCR Assay for Detection of Pneumocystis Jiroveci. Transpl. Infect. Dis. 2007, 9, 196-202. [CrossRef] [PubMed] 
51. Guillaud-Saumur, T.; Nevez, G.; Bazire, A.; Virmaux, M.; Papon, N.; Le Gal, S. Comparison of a Commercial Real-Time PCR Assay, RealCycler ${ }^{\circledR}$ PJIR Kit, Progenie Molecular, to an in-House Real-Time PCR Assay for the Diagnosis of Pneumocystis Jirovecii Infections. Diagn. Microbiol. Infect. Dis. 2017, 87, 335-337. [CrossRef] [PubMed]

52. Huggett, J.F.; Taylor, M.S.; Kocjan, G.; Evans, H.E.; Morris-Jones, S.; Gant, V.; Novak, T.; Costello, A.M.; Zumla, A.; Miller, R.F. Development and Evaluation of a Real-Time PCR Assay for Detection of Pneumocystis Jirovecii DNA in Bronchoalveolar Lavage Fluid of HIV-Infected Patients. Thorax 2008, 63, 154-159. [CrossRef]

53. McTaggart, L.R.; Wengenack, N.L.; Richardson, S.E. Validation of the MycAssay Pneumocystis Kit for Detection of Pneumocystis Jirovecii in Bronchoalveolar Lavage Specimens by Comparison to a Laboratory Standard of Direct Immunofluorescence Microscopy, Real-Time PCR, or Conventional PCR. J. Clin. Microbiol. 2012, 50, 1856-1859. [CrossRef] [PubMed]

54. Dalpke, A.H.; Hofko, M.; Zimmermann, S. Development and Evaluation of a Real-Time PCR Assay for Detection of Pneumocystis Jirovecii on the Fully Automated BD MAX Platform. J. Clin. Microbiol. 2013, 51, 2337-2343. [CrossRef] [PubMed]

55. Chien, J.-Y.; Liu, C.-J.; Chuang, P.-C.; Lee, T.-F.; Huang, Y.-T.; Liao, C.-H.; Hung, C.-C.; Sheng, W.-H.; Yu, C.-J.; Hsueh, P.-R. Evaluation of the Automated Becton Dickinson MAX Real-Time PCR Platform for Detection of Pneumocystis Jirovecii. Future Microbiol. 2017, 12, 29-37. [CrossRef] [PubMed]

56. Thomas, C.F.; Limper, A.H. Pneumocystis Pneumonia. N. Engl. J. Med. 2004, 350, 2487-2498. [CrossRef]

57. Pereira, R.M.; Müller, A.L.; Zimerman, R.A.; Antunes, D.B.; Zinn, V.F.; Friaza, V.; de la Horra, C.; Calderón, E.J.; Wissmann, G. High Prevalence of Pneumocystis Jirovecii Colonization among HIV-Positive Patients in Southern Brazil. Med. Mycol. 2014, 52, 804-809. [CrossRef]

58. Le Gal, S.; Damiani, C.; Rouillé, A.; Grall, A.; Tréguer, L.; Virmaux, M.; Moalic, E.; Quinio, D.; Moal, M.-C.; Berthou, C.; et al. A Cluster of Pneumocystis Infections among Renal Transplant Recipients: Molecular Evidence of Colonized Patients as Potential Infectious Sources of Pneumocystis Jirovecii. Clin. Infect. Dis. 2012, 54, e62-e71. [CrossRef]

59. Samuel, C.M.; Whitelaw, A.; Corcoran, C.; Morrow, B.; Hsiao, N.-Y.; Zampoli, M.; Zar, H.J. Improved Detection of Pneumocystis Jirovecii in Upper and Lower Respiratory Tract Specimens from Children with Suspected Pneumocystis Pneumonia Using Real-Time PCR: A Prospective Study. BMC Infect. Dis. 2011, 11, 329. [CrossRef]

60. Pennington, K.; Wilson, J.; Limper, A.H.; Escalante, P. Positive Pneumocystis Jirovecii Sputum PCR Results with Negative Bronchoscopic PCR Results in Suspected Pneumocystis Pneumonia. Can. Respir. J. 2018, 2018, 6283935. [CrossRef] [PubMed]

61. Rao, M.; Rashid, F.A.; Sabri, F.S.A.H.; Jamil, N.N.; Zain, R.; Hashim, R.; Amran, F.; Kok, H.T.; Samad, M.A.A.; Ahmad, N. Comparing Nasopharyngeal Swab and Early Morning Saliva for the Identification of Severe Acute Respiratory Syndrome Coronavirus 2 (SARS-CoV-2). Clin. Infect. Dis. 2021, 72, e352-e356. [CrossRef]

62. Medrano, F.J.; Montes-Cano, M.; Conde, M.; de la Horra, C.; Respaldiza, N.; Gasch, A.; Perez-Lozano, M.J.; Varela, J.M.; Calderon, E.J. Pneumocystis Jirovecii in General Population. Emerg. Infect. Dis. 2005, 11, 245-250. [CrossRef]

63. Respaldiza, N.; Montes-Cano, M.A.; Friaza, V.; Muñoz-Lobato, F.; Medrano, F.J.; Varela, J.M.; Calderon, E.; De la Horra, C. Usefulness of Oropharyngeal Washings for Identifying Pneumocystis Jirovecii Carriers. J. Eukaryot. Microbiol. 2006, 53 (Suppl. 1), S100-S101. [CrossRef]

64. Matos, O.; Costa, M.C.; Lundgren, B.; Caldeira, L.; Aguiar, P.; Antunes, F. Effect of Oral Washes on the Diagnosis of Pneumocystis Carinii Pneumonia with a Low Parasite Burden and on Detection of Organisms in Subclinical Infections. Eur. J. Clin. Microbiol. Infect. Dis. 2001, 20, 573-575. [CrossRef] [PubMed]

65. Vera, C.; Aguilar, Y.A.; Vélez, L.A.; Rueda, Z.V. High Transient Colonization by Pneumocystis Jirovecii between Mothers and Newborn. Eur. J. Pediatr. 2017, 176, 1619-1627. [CrossRef] [PubMed] 